\title{
The Influence of Realistic Mathematical Approach to Understanding Concept and the Mathematical Connection Ability of Islamic Private Vocational School Students Hikmatul Fadhillah Medan Class VII
}

\author{
Siska Adliani' ${ }^{1}$ Asmin ${ }^{2}$, Hasratuddin ${ }^{2}$ \\ ${ }^{1}$ Postgraduate Basic Education Student, Universitas Negeri Medan, Indonesia \\ ${ }^{2}$ Postgraduate Basic Education Lecturer, Universitas Negeri Medan, Indonesia \\ Siskaadliani03@gmail.com
}

\section{Abstract}

The purpose of this research in the design of Quasi Experiment is to investigate the effect of the Realistic Mathematical Approach $(P M R)$ on the ability to understand students' mathematical concepts, the ability of students' mathematical connections and the interaction between learning approaches with students' initial abilities on the differences in the influence of students understanding abilities and students' mathematical connections. The research was carried out at Hikmatul Fadhillah Islamic Private Middle School in class VII with 118 students. This research is an experimental study with a test-post-test control group design research design. The population in this study were all students of class VII by taking a sample of two classes (experimental class and control class) through random sampling techniques. Data obtained through KAM test, mathematics concept comprehension ability test, and mathematics connection ability test. Data were analyzed by two-way ANAVA test. Before using the two-way ANAVA test homogeneity tests were used in the study and normality in this study was 5\% significant. The results of data analysis showed that the average concept comprehension ability test was 71.43 and the control class was 62.54, with a value of sig $=0$ with $0<50.05$, so there was a difference in the effect of students' understanding of mathematics concepts being taught with a mathematical approach realistic mathematics (PMR) with the usual learning approach, the average test ability of experimental and control mathematical connections is 70.43 and 67.76 with sig $=0$, with $0<\propto 0.05$, then there are differences in the effect of students' mathematical connection abilities taught with a realistic mathematics approach (PMR) and conventional learning approach, a significant value of 0.127 , because $0.127>0.05$.

\section{Keywords}

PMR approach; concept comprehension ability; mathematical connection ability

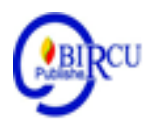

\section{Introduction}

In the teaching process, the most important thing is achievement of the goal that students are able to understand something based on their learning experience. The ability to understand is very fundamental, because understanding will be able to achieve procedural knowledge. According to Ernawati (2003: 8) stated that what is meant by understanding is the ability to capture notions such as being able to express a material presented in other forms that can be understood, able to provide interpretation and be able to classify it.

Each mathematics learning material contains a number of concepts that students must like. Understanding the concept according to Ruseffendi (1998: 157) is an abstract idea that 
allows us to classify or classify objects or events that are examples and not examples of these ideas.

Understanding the concept is very important because the mastery of the concept will facilitate students in learning mathematics. In each learning effort is emphasized more on mastery of concepts so that students have a good basic stock to achieve other basic abilities such as reasoning, communication, connection and problem solving. Concept mastery is the level of student learning outcomes so that they can define or explain some or define learning material with use own sentences. With the ability of students to explain or define, the student has understood the concepts or principles of a lesson even though the explanation given has a sentence structure that is not the same as the concept given but the intent is the same.

Based on the results of preliminary observations conducted by researchers describe that students have difficulty in solving problems understanding mathematical concepts. This student difficulty is a serious problem that must be addressed, because of an understanding of the basic concepts of mathematics. A concept will be better understood and remembered by students if the concept is presented through an interesting procedure, even though the time provided is limited.

Understanding concepts is also a very important factor, because understanding concepts achieved by students cannot be separated from the learning problem which is a tool to measure the extent of mastery of the material being taught. To achieve a good understanding of the concept required an appropriate learning atmosphere, so students always improve their learning activities and are excited. With the effective understanding of student concepts, meaning learning objectives can be achieved properly.

According to Anderson and Krathwohl (in Afriati, 2011) understanding of concepts in mathematics learning should also be instilled in every student by the teacher as an educator. Because without understanding, students cannot apply procedures, concepts or processes. Mathematics will be understood and understood when students learn about the connection between information received and the network of representation. Students are said to understand if they can construct the meaning of learning messages, whether they are oral, written or graphic.

In learning mathematics in addition to the ability to understand concepts students must also have the ability to connect mathematics. The National Council of Teachers of Mathematics (NCTM, 2000) formulates the objectives of mathematics learning, which consists of five basic mathematical abilities that are standard namely problem solving, reasoning and proof, communication, communication, connections) and representation. By referring to the five NCTM capability standards above, the mathematics learning objectives set out in the 2006 curriculum issued by the Ministry of National Education essentially cover (1) connections between concepts in mathematics and their use in problem solving, (2) reasoning, (3) problem solving, (4) communication and representation, and (5) affective factors. In both statements, the ability of mathematical connections is a strategic ability that is the goal of learning mathematics.

So there needs to be a movement to make fundamental changes in mathematics education, especially from the learning strategy and approach, because until now there are still so many students complaining and thinking that mathematics is very difficult and a scourge, as a result they do not like or even hate mathematics. So it is indicated that for most students, mathematics learning has not been able to change the affective domain (attitudes, interests, values, choices, academic confidence, focus of control, anxiety and motivation) and 
cognitive (knowledge, understanding, application, analysis, synthesis and evaluation) students towards better.

For this reason, various efforts need to be made, including improvements to the approach in learning mathematics that teachers do now. Thus the selection of a suitable learning approach model can arouse and encourage the emergence of student activities so as to enhance understanding of concepts and ability of students' mathematical connections to mathematical material. From a teacher-oriented mathematics learning approach to a studentoriented learning approach. Then the teaching work for a teacher is not just completing a number of subject matter but the teacher must really be able to instill concepts in the hope that students can master them. One of several learning approaches that is thought to help foster students' understanding of mathematical concepts is the Realistic Mathematics Approach.

Because the realistic mathematical approach has characteristics and principles that enable students to develop optimally, such as the freedom of students to express their opinions, linking daily life experiences and real things of students with mathematical concepts learned, and making models that can facilitate students in completing problem. According to Ruseffendi (2004: 2) the reason for using a realistic mathematical approach in school is because mathematics can be used in various circumstances, used by every human being in every activity both mindset and mathematics itself, and students who attend school have diverse abilities. In learning that applies a realistic mathematical approach inviting students and active teachers, learning is centered on students and teachers as facilitators, presents realistic or contextual problems and the teacher provides opportunities for students to solve problems independently so that learning is more meaningful.

The ability to understand mathematical concepts and the ability of students' mathematical connections are not only driven from learning using PMR, but are also influenced by their initial mathematical abilities as well. Early math skills (KAM) are abilities that are needed by a student to achieve instructional goals. Mathematical initial ability is the initial knowledge ability that must be possessed by a student which is a prerequisite for learning further lessons and so that he can easily continue his education to the next level.

Relating to the learning approach and the initial ability of mathematics to the ability to understand concepts and the ability to connect mathematics. In a realistic mathematics learning approach, where the initial ability of mathematics is one of its characteristics plays a very important role in helping students solve mathematical problems. For students who are smart (high ability) early mathematical abilities may see the problem is not too difficult for him to solve. Conversely for students of moderate and low ability for them the initial mathematical ability becomes a benchmark in the process of solving problems. Therefore in this case the researcher will see first the mathematical initial ability of each student who aims at forming heterogeneous groups in the learning process.

Based on the explanation above, it can be seen that the success of several countries mentioned in applying the realistic mathematics approach has several advantages over other learning approaches, including: a realistic mathematical approach to improve student learning outcomes and achievements, obtain higher scores, motivate students in learning mathematics, can improve their ability logical thinking, mathematical communication and others. So that the application of a realistic mathematical approach is expected and strived to improve understanding of students' mathematical concepts, learning that occurs more meaningfully and is able to change the affective and cognitive domains of students towards better. 
During this time, a realistic mathematical approach has never been applied at SMP IT Hikmatul Fadhillah Medan, thus encouraging researchers to apply a realistic mathematical approach. The subject chosen is one of mathematical material that is abstract and can be linked in everyday life, namely the subject of Algebra.

The objectives of this study are: 1) To analyze differences in the ability to understand mathematical concepts of students taught with realistic mathematical approaches and ordinary learning approaches, 2) To analyze differences in mathematical connection abilities of students taught with realistic mathematical approaches and ordinary learning approaches, 3) To analyze the interaction between learning with the initial ability of mathematics on the ability to understand the mathematical concepts of students of SMP IT Hikmatul Fadhillah Medan, 4) To analyze the interaction between learning with the initial mathematical ability of the mathematical connection ability of students of SMP IT Hikmatul Fadhillah Medan.

\section{Review of Literature}

\subsection{Ability to Understand Math Concepts}

The ability to understand mathematical concepts wants students to be able to use or apply what they have understood into learning activities. If students already have a good understanding, then the student is ready to give definitive answers to statements or problems in learning.

\subsection{Mathematical Connection Ability}

Mathematical connection ability is the ability of someone to connect a mathematical idea with other mathematical ideas, and an indicator of someone having a good connection ability is students who are able to connect between mathematical topics, are able to connect between other disciplines and are able to connect with the real world / daily life -day.

\subsection{Realistic Mathematics Learning Approach}

In Indonesia, RME is better known as PMRI (Indonesian Realistic Mathematical Approach). However, in the study of this paper, the term used is the Realistic Mathematical Approach (PMR). The essence of this approach is to relate subject matter to real life and motivate students to associate the knowledge they learn with students' daily lives. This means that mathematics must be close to the child and relevant to real life.

\subsection{Beginning Mathematical Ability of Students}

Initial ability is the initial prerequisite ability or basic ability of students which is an illustration of student readiness that is used so that students are equipped to receive higher learning mathematics concepts. This initial ability can be known through the initial test action before learning takes place. With so the weight of the material prepared by the teacher in accordance with the initial abilities possessed by students so that the learning process is more conceptualized and attractive to students which in turn can improve students' mathematical abilities. Through the initial mathematical ability test, it can be criticized between students whose initial mathematical ability is high if the student meets the KKM grades of the school, while the KKM score at SMP IT Hikmatul Fadhillah is 75 and students whose initial mathematical ability is low if the student does not meet the KKM grade standard school. 


\section{Research Methods}

The research was carried out in Hikmatul Fadhillah Islamic Private Middle School in class VII as many as 118 students. This research is an experimental study with a test-post-test control group design research design. The population in this study were all students of class VII by taking a sample of two classes (experimental class and control class) through random sampling techniques. Data obtained through KAM tests, tests of understanding mathematical concepts, and tests of mathematical connection abilities. Data were analyzed by two-way ANAVA test. Before using the two-way ANAVA test homogeneity tests were used in the study and normality in this study was $5 \%$ significant.

\section{Discussion}

\section{Mathematical Concept Understanding Ability Test Results}

Table 1. Description of Data Ability of Understanding Mathematical Concepts of Students in Both Learning Groups

\begin{tabular}{ccccc}
\hline \multirow{2}{*}{ Statistics } & \multicolumn{4}{c}{ Learning } \\
\cline { 2 - 5 } & \multicolumn{3}{c}{ PMR } & \multicolumn{2}{c}{ Ordinary Learning } \\
\cline { 2 - 5 } & Pretest & Postest & Pretest & Postest \\
\hline $\mathbf{N}$ & 42 & 42 & 40 & 40 \\
\hline Average & 60,57 & 71,43 & 57,70 & 62,45 \\
\hline $\begin{array}{c}\text { Standard } \\
\text { Deviation }\end{array}$ & 12,363 & 9,412 & 14,872 & 12,308 \\
\hline
\end{tabular}

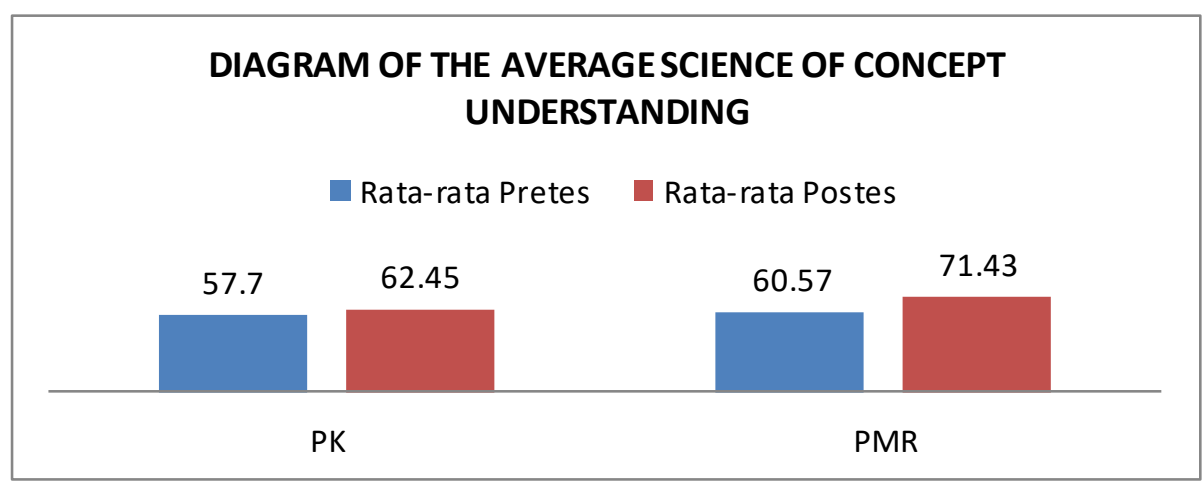

Figure 1. Average Score of Ability to Understand Mathematical Concepts

Table 2. Average Ability of Understanding Mathematical Concepts of PMR Groups and Ordinary Groups Based on Students' Early Mathematical Capabilities

\begin{tabular}{cllccc}
\hline \multirow{2}{*}{ Learning } & \multirow{2}{*}{$\begin{array}{c}\text { Early Mathematical } \\
\text { Ability of Students }\end{array}$} & \multicolumn{4}{c}{ Concept Understanding Ability } \\
\cline { 3 - 6 } & High (9) & $\bar{x}$ & Std & Min & Max \\
\cline { 2 - 6 } PMR & Average (25) & 83,67 & 5,477 & 79 & 93 \\
\cline { 2 - 6 } & Low (8) & 70,68 & 5,786 & 60 & 78 \\
\cline { 2 - 6 } & Total (42) & 60,00 & 5,099 & 55 & 65 \\
\hline Ordinary & High (8) & $\mathbf{7 1 , 4 3}$ & $\mathbf{9 , 4 1 2}$ & $\mathbf{5 5}$ & $\mathbf{9 3}$ \\
\hline
\end{tabular}




\begin{tabular}{llcccc}
\hline Average (28) & 60,43 & 8,656 & 43 & 75 \\
\cline { 2 - 5 } Low (4) & 44,25 & 6,500 & 35 & 50 \\
\cline { 2 - 5 } Total (40) & $\mathbf{6 2 , 4 5}$ & $\mathbf{1 2 , 3 0 8}$ & $\mathbf{3 5}$ & $\mathbf{8 5}$ \\
\hline
\end{tabular}

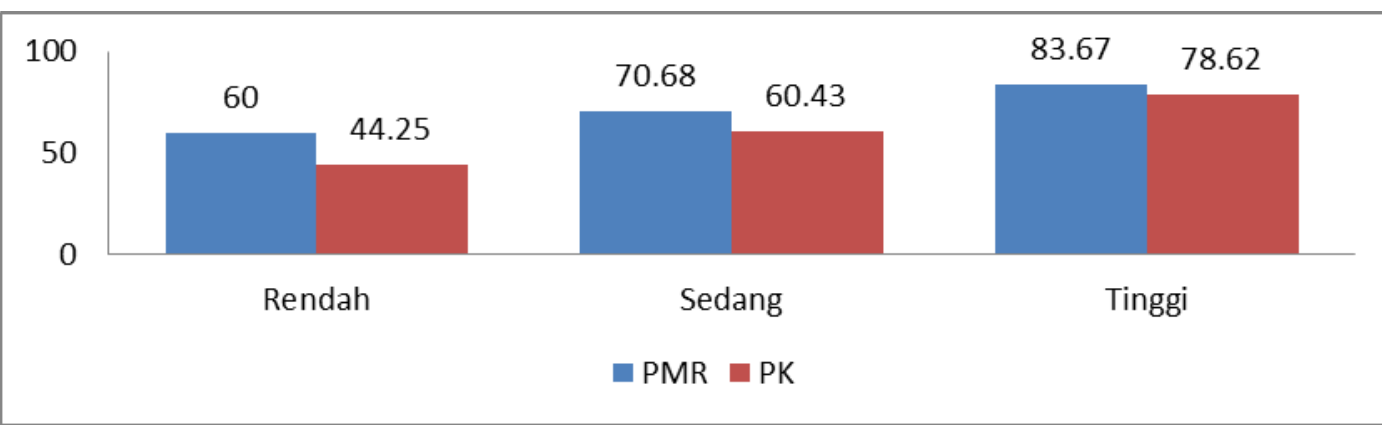

Figure 2. Average Score of Mean Ability to Understand Math Concepts Based on Learning Factors and Mathematical Ability

Descriptive there are several conclusions regarding the ability to understand the concepts expressed by table 4.8, Figure 1 and Figure 2 above, namely:

1. In high-ability students, the average ability to understand mathematical concepts given the PMR 83.67 approach looks higher than the average ability to understand mathematical concepts given the usual approach 78.62.

2. In students who are moderately capable, the average ability of understanding mathematical concepts of students who are given a PMR approach of 70.68 looks higher than the average ability of understanding concepts given the usual approach of 60.43 .

3. In students with low ability, the average ability to understand mathematical concepts given the PMR 60 approach looks higher than the average ability to understand mathematical concepts given the usual approach 44.25.

4. The ability of understanding the mathematical concepts of the experimental group students was 71.43 higher than the average ability of understanding the mathematical concepts of the control class students by 62.45 .

5. Whereas the standard deviation of the experimental group and the control group is not much different 9.412 and 12.308 .

To find out the significance of the truth of the conclusions above, statistical tests were carried out using two-way ANAVA. Statistical tests with two-way ANAVA are used to test the presence or absence of differences in the ability to understand mathematical concepts between students who are given the PMR approach compared with students who are given Normal learning, as well as the presence or absence of PMR and Ordinary learning interactions and students' mathematical abilities (high, moderate and low) on the ability to understand mathematical concepts. The statistical analysis used was two-way ANAVA.

ANAVA Statistical Analysis of two paths

Table 3. ANAVA Test Results Ability to Understand Students' Mathematical Concepts Tests of Between-Subjects Effects

Dependent Variable: KPK

\begin{tabular}{|l|c|c|c|c|c|}
\hline Source & $\begin{array}{c}\text { Type III Sum } \\
\text { of Squares }\end{array}$ & Df & $\begin{array}{c}\text { Mean } \\
\text { Square }\end{array}$ & F & Sig. \\
\hline
\end{tabular}




\begin{tabular}{|l|r|r|r|r|r|}
\hline Corrected & $7524.807^{\mathrm{a}}$ & 5 & 1504.961 & 31.568 & .000 \\
Model & 229969.696 & 1 & 229969.696 & 4823.903 & .000 \\
Intercept & 5807.456 & 2 & 2903.728 & 60.909 & .000 \\
KAM & 1383.068 & 1 & 1383.068 & 29.012 & .000 \\
Kelas & 202.132 & 2 & 101.066 & 2.120 & .127 \\
KAM * Kelas & 3623.144 & 76 & 47.673 & & \\
Error & 379514.000 & 82 & & & \\
Total & 11147.951 & 81 & & & \\
Corrected & & & & \\
Total & & & & \\
\hline
\end{tabular}

a. R Squared $=.675$ (Adjusted R Squared $=.654$ )

\section{a. Learning Approach Factors}

The test is based on a hypothesis, namely:

$\mathrm{H}_{0}$ : There is no difference in the effect of students' understanding of mathematical concepts taught by the Realistic Mathematics Approach and the Ordinary Learning Approach.

$\mathrm{H}_{\mathrm{a}}$ : There is a difference in the effect of students' understanding of mathematical concepts taught by the Realistic Mathematics Approach and the Ordinary Learning Approach.

Hypothesis in statistical form:

$\mathrm{H}_{0}: \mu_{K P K A}=\mu_{K P K B}$

$\mathrm{H}_{\mathrm{a}}: \mu_{\text {KPKA }} \neq \mu_{K P K B}$

Based on the ANAVA test results in table 3, the difference in the ability to understand mathematical concepts of students with an F count of 29,012 with a significance of $\alpha=0,000$. Because the significant value of the ability to understand mathematical concepts is smaller than $\alpha=0.05$, it can be concluded that there are differences in the ability to understand mathematical concepts taught by the Realistic Mathematical Approach (PMR) and the

Ordinary Learning Approach so that $\mathrm{H}_{0}$ is rejected.

1. Interaction between learning approaches and students' mathematical abilities

The hypothesis proposed for ANAVA is formulated as follows:

$\mathrm{H}_{0}$ : There is no interaction between the learning approach and the initial ability to influence the ability to understand students' mathematical concepts.

$\mathrm{H}_{\mathrm{a}}$ : There is an interaction between the learning approach with the initial ability to influence the ability to understand students' mathematical concepts.

Hypothesis in statistical form:

$\mathrm{H}_{0}: \mu_{11}-\mu_{12}=\mu_{21}-\mu_{22}=\mu_{31}-\mu_{32}$

$\mathrm{H}_{\mathrm{a}}$ : There is at least one difference in the average ability of students to understand mathematical concepts that are different from the others.

Information :

$\mu_{11}$ : High average ability and PMR approach

$\mu_{12}$ : High average ability and Ordinary approach

$\mu_{21}$ : Average ability and PMR approach

$\mu_{22}$ : Average ability and Normal approach

$\mu_{31}$ : Low capability average and PMR approach

$\mu_{32}$ : Low average ability and Ordinary approach

From table 3 the information is obtained that the significance value (sig) for the KAM category is 0,000 less than $\alpha=0.05$ which means that $H_{0}$ is rejected. So the KAM category 
influences differences in the ability of students to understand mathematical concepts. From Table 3 it can also be seen that the significance value (sig) for the class or learning category is 0,000 less than $\alpha=0.05$ which means that $\mathrm{H}_{0}$ is rejected. This means that the learning factor of students 'understanding of mathematical concepts there are differences in the ability to understand students' mathematical concepts, if grouped based on the approach applied. Therefore, it can be concluded that there are differences in the ability of students to understand mathematical concepts between learning using PMR and Conventional.

Whereas for interaction from Table 3 it can be seen that for learning and KAM factors, $F$ values obtained for learning interactions and students' initial mathematical abilities were 2.120 and significance values were 0.127 . Because the significance value is greater than 0.05 , it can be concluded that reject $\mathrm{H}_{\mathrm{a}}$ and reject $\mathrm{H}_{0}$ which means there is no interaction between the learning approach with KAM on the ability to understand students' mathematical concepts can be accepted. This can also be interpreted, there is no shared influence given by the learning approach and KAM on the ability to understand students' mathematical concepts. This means that the difference in the average score of students' understanding of mathematical concepts with the KAM category in a row that is high, medium and low between those taught with the approach (PMR) and Ordinary is not significantly different. More clearly, there is no interaction between the learning approach and students 'initial mathematical abilities with the ability to understand students' mathematical concepts, presented in Figure 3 below:

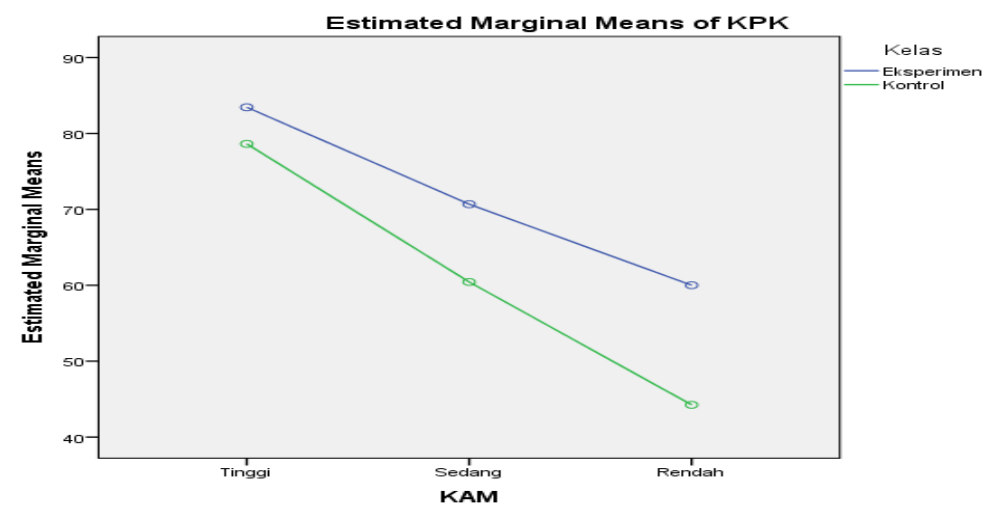

Figure 3. The interaction between the learning approach and students 'initial ability to the ability to understand students' mathematical concepts

2. Student Mathematics Ability Test Results

Table 4. Data Description of the Mathematical Connection Ability of the Second Student Learning Group

\begin{tabular}{ccccc}
\hline \multirow{2}{*}{ Statistics } & \multicolumn{4}{c}{ Learning } \\
\cline { 2 - 5 } & Pretest & Postest & Pretest & Postest \\
\cline { 2 - 5 } & 42 & 42 & 40 & 40 \\
\hline $\mathbf{N}$ & 63,98 & 70,43 & 61,70 & 67,76 \\
\hline Average & 11,821 & 10,567 & 11,889 & 10,420 \\
\hline Standard Deviation & & &
\end{tabular}




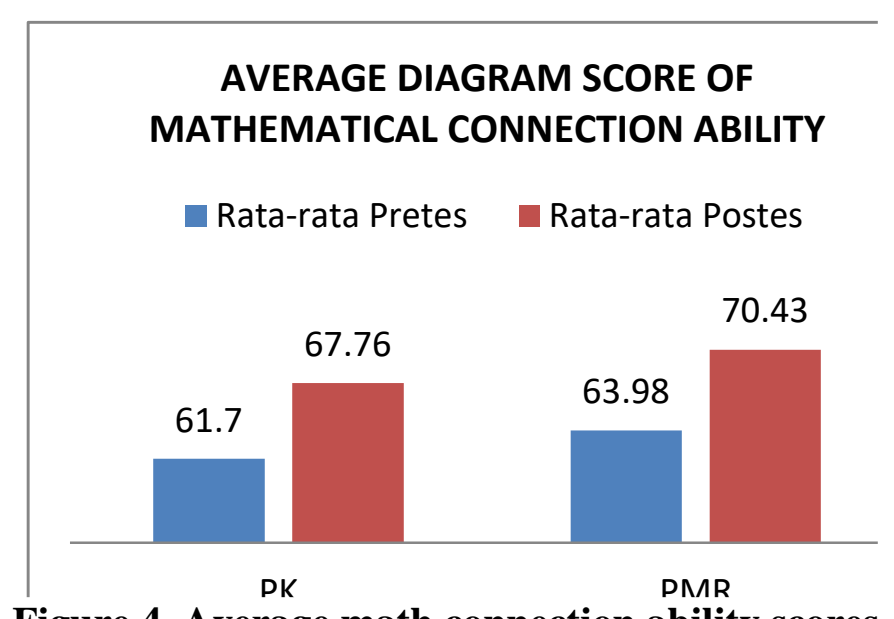

Figure 4. Average math connection ability scores

Table 5. Average Mathematics Connection Ability of PMR Groups and Ordinary Groups Based on Students' Early Mathematical Capabilities

\begin{tabular}{cllccc}
\hline \multirow{2}{*}{ Learning } & Early Mathematical & \multicolumn{4}{c}{ Mathematical Connection Ability } \\
\cline { 3 - 6 } & Ability of Students & $\bar{x}$ & Std & Min & Max \\
\hline \multirow{5}{*}{ PMR } & High (9) & 82,78 & 3,866 & 80 & 90 \\
\cline { 2 - 6 } & Average (25) & 71,00 & 6,232 & 60 & 80 \\
\cline { 2 - 6 } & Low (8) & 54,75 & 5,064 & 45 & 60 \\
\cline { 2 - 6 } & Total (42) & $\mathbf{7 0 , 4 3}$ & $\mathbf{1 0 , 5 6 7}$ & $\mathbf{4 5}$ & $\mathbf{9 0}$ \\
\hline \multirow{5}{*}{ Ordinary } & High (8) & 82,00 & 2,330 & 80 & 85 \\
\cline { 2 - 6 } & Average (28) & 67,11 & 5,711 & 57 & 79 \\
\cline { 2 - 6 } & Low (4) & 48,50 & 5,745 & 45 & 57 \\
\cline { 2 - 6 } & Total (40) & $\mathbf{6 8 , 2 3}$ & $\mathbf{1 0 , 2 8 7}$ & $\mathbf{4 5}$ & $\mathbf{8 5}$ \\
\hline
\end{tabular}

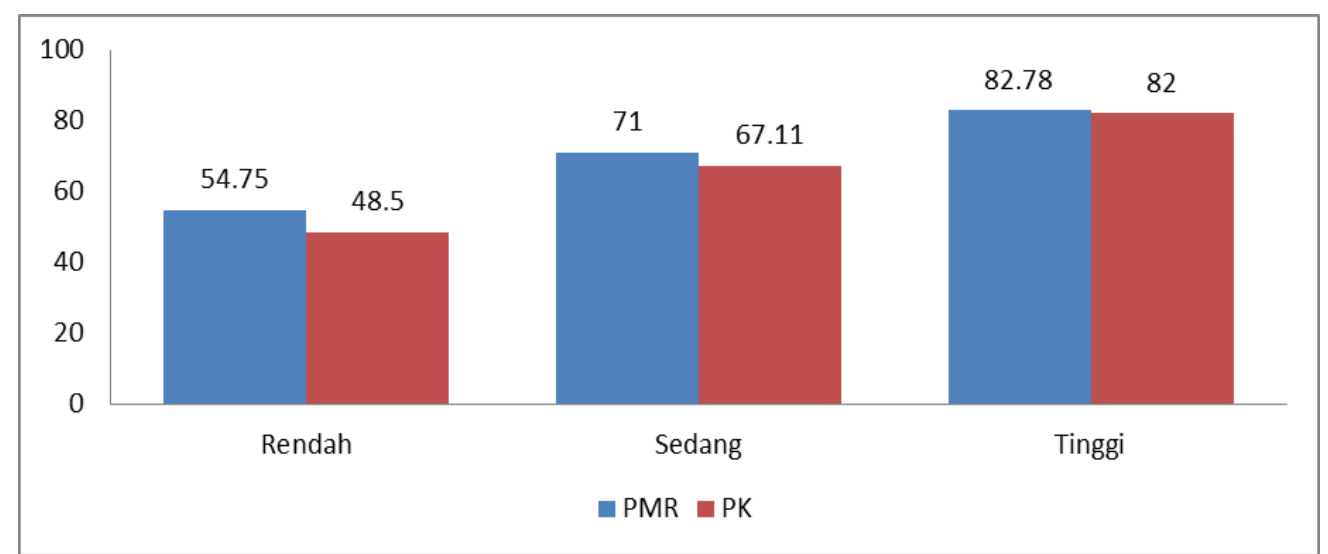

Figure 5. Average Mean and Standard Deviation Scores of Mathematics Connection Abilities Based on Learning

0-Descriptively there are several conclusions regarding the mathematical connection ability revealed by table 5 and Figure 5 above, namely: 
1. In high-ability students, the average mathematical connection ability given the PMR approach 82.78 looks higher than the average mathematical connection ability given the usual approach 82 .

2. In students who are moderately capable, the average mathematical connection ability of students who are given the PMR 71 approach looks higher than the average mathematical connection ability given the usual approach 67.11 .

3. In students with low ability, the average mathematical connection ability given the PMR approach 54.75 looks higher than the average mathematical connection ability given the usual approach 48.5 .

4. The mathematical connection ability of the experimental group students was 70.43 higher than the mean of the mathematical connection ability of the control class students by 68.23 .

5. Whereas the standard deviation of the experimental group and the control group is not much different from 10,567 and 10.287.

To find out the significance of the truth of the conclusions above, statistical tests were carried out using two-way ANAVA. Statistical tests with two-way ANAVA are used to test the presence or absence of differences in the ability of mathematical connections between students who are given the PMR approach compared with students who are given Normal learning, as well as the presence or absence of PMR and Ordinary learning interactions and students' mathematical abilities (high, medium and low) on the ability of mathematical connections. The statistical analysis used was two-way ANAVA.

\section{ANAVA Statistical Analysis of two paths}

Table 6. ANAVA Test Results for Students' Mathematical Connection Ability Tests of Between-Subjects Effects

Dependent Variable: KKM

\begin{tabular}{|l|r|r|r|r|r|}
\hline Source & $\begin{array}{c}\text { Type III Sum } \\
\text { of Squares }\end{array}$ & df & \multicolumn{1}{c|}{$\begin{array}{c}\text { Mean } \\
\text { Square }\end{array}$} & \multicolumn{1}{c|}{ F } & Sig. \\
\hline Corrected & $6591.717^{\mathrm{a}}$ & 5 & 1318.343 & 47.156 & .000 \\
Model & 240629.776 & 1 & 240629.776 & 8607.130 & .000 \\
Intercept & 6223.027 & 2 & 3111.514 & 111.296 & .000 \\
KAM & 186.593 & 1 & 186.593 & 6.674 & .012 \\
Kelas & 57.896 & 2 & 28.948 & 1.035 & .360 \\
KAM * Kelas & 2124.734 & 76 & 27.957 & & \\
Error & 404519.000 & 82 & & & \\
Total & 8716.451 & 81 & & & \\
Corrected & & & & \\
Total & & & & \\
\hline
\end{tabular}

a. R Squared $=.756$ (Adjusted R Squared $=.740$ )

1. Learning approach factors

The test is based on a hypothesis, namely:

$\mathrm{H}_{0}$ : There is no difference in the effect of students' mathematical connection abilities taught by the Realistic Mathematics Approach and the Ordinary Learning Approach.

$\mathrm{H}_{\mathrm{a}}$ : There is a difference in the effect of students' mathematical connection abilities taught by the Realistic Mathematical Approach and the Ordinary Learning Approach. 
Hypothesis in statistical form:

$\mathrm{H}_{0}: \mu_{K P K A}=\mu_{K P K B}$

$\mathrm{H}_{\mathrm{a}}: \mu_{K P K A} \neq \mu_{K P K B}$

Based on the ANAVA test results in table 6, the difference in the ability of students' mathematical connections with Fcount 6.674 with a significance $\alpha=0.012$. Because the significant value of the mathematical connection ability is smaller than $\alpha=0.05$, it can be concluded that there are differences in the mathematical connection ability taught by the Realistic Mathematical Approach (PMR) and the Ordinary Learning Approach accepted so that $\mathrm{H}_{0}$ is rejected.

2. Interaction between learning approaches and students' mathematical abilities

The hypothesis proposed for ANAVA is formulated as follows:

$\mathrm{H}_{0}$ : There is no interaction between the learning approach and the initial ability to influence students' mathematical connection abilities.

$\mathrm{H}_{\mathrm{a}}$ : There is an interaction between the learning approach and the initial ability to influence students' mathematical connection abilities.

Hypothesis in statistical form:

$\mathrm{H}_{0}: \mu_{11}-\mu_{12}=\mu_{21}-\mu_{22}=\mu_{31}-\mu_{32}$

Ha: At least one group difference in average students' mathematical connection ability is different from the others.

Information :

$\mu_{11}$ : High average ability and PMR approach

$\mu_{12}$ : High average ability and Ordinary approach

$\mu_{21}$ : Average ability and PMR approach

$\mu_{22}$ : Average ability and Normal approach

$\mu_{31}$ : Low capability average and PMR approach

$\mu_{32}$ : Low average ability and Ordinary approach

From table 6 obtained information that the significance value (sig) for the KAM category is 0,000 less than $\alpha=0.05$ which means that $\mathrm{H}_{0}$ is rejected. So the KAM category affects the difference in students' mathematical connection abilities. From Table 6 it can also be seen that the significance value (sig) for the class or learning category is 0,000 less than $\alpha$ $=0.05$ which means that $\mathrm{H}_{0}$ is rejected. This means that there are differences in students' mathematical connection ability learning abilities, if grouped according to the approach applied. Therefore, it can be concluded that there are differences in students' mathematical connection abilities between those learning using PMR and Conventional.

As for the interactions from Table 6, it can be seen that for learning and KAM factors, the $\mathrm{F}$ value for learning interactions and students' initial mathematical abilities is 1.035 and the significance value is 0.36 . Because the significance value is greater than 0.05 , it can be concluded that reject $\mathrm{H}_{\mathrm{a}}$ and reject $\mathrm{H}_{0}$, which means there is no interaction between the learning approach with KAM on the ability of students' mathematical connections can be accepted. This can also be interpreted, there is no shared influence given by the learning approach and KAM on the ability of students' mathematical connections. This means that the difference in the average score of students' mathematical connection ability with the KAM category in a row that is high, medium and low between those taught with the approach (PMR) and Ordinary is not significantly different. More clearly, there is no interaction between learning approaches and students 'initial mathematical abilities with the ability to understand students' mathematical concepts, presented in Figure 6 below: 


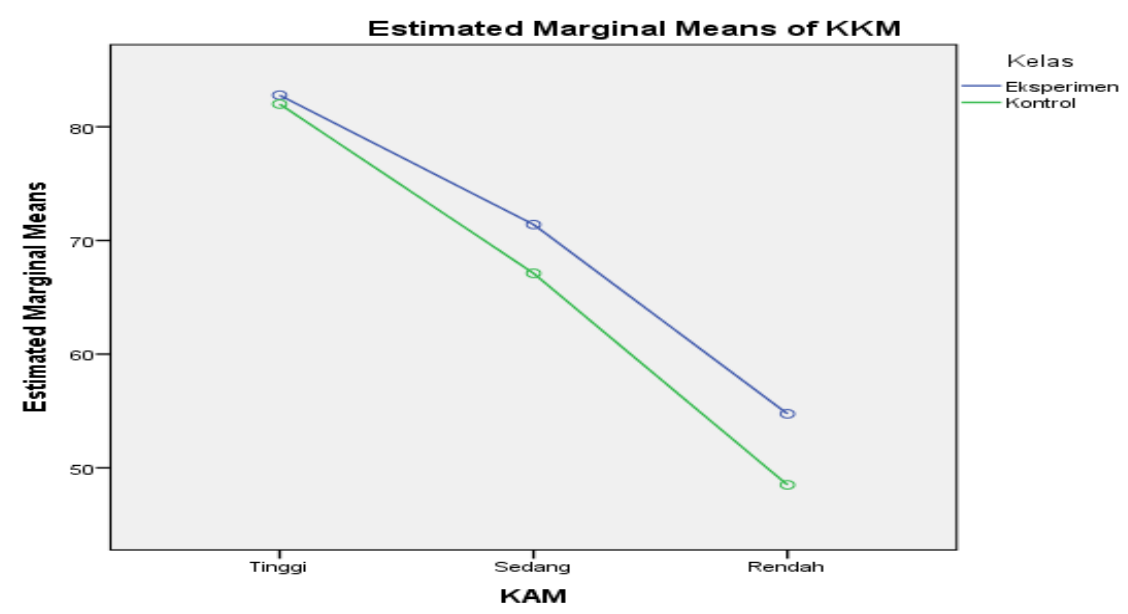

Figure 6. The interaction between the learning approach and the students 'initial ability to the students' mathematical connection abilities

\section{Conclusion}

1. There is a difference in the effect of students' understanding of mathematical concepts being taught with realistic mathematics approaches and conventional learning approaches.

2. There is a difference in the effect of students' mathematical connection abilities that are taught with realistic mathematics approaches and conventional learning approaches.

3. There is no interaction between the learning approach with the initial ability of mathematics to the ability to understand students' mathematical concepts.

4. There is no interaction between the learning approach with the initial ability of mathematics to the ability of students' mathematical connections.

\section{References}

Arends, Richard . 2008. Learning to Teach. Yogyakarta : Pustaka Pelajar.

Arikunto. 2009. Prosedur Penelitian Suatu Pendekatan Praktik. Edisi Revisi 6. Jakarta : Rineka Cipta.

Bell, H.F. 1981. Teaching and Learning Mathematics (In Secondary School). Iowa : Wm. C. Brown Company.

Bergeson, T. 2000. Teaching and Learning Mathematics. Washington : State Superintendent of Public Instruction.

Ernawati. 2003. Meningkatkan Kemampuan Pemahaman Konsep Matematika Siswa SMU Melalui Pembelajaran Berbasis Masalah. Skripsi Jurusan Pendidikan Matematika FPMIPA UPI (tidak dipublikasikan).

Hiebert, J \& Carpenter, (TP) 1992. Learning and Teaching with Understanding. Dalam Douglas A. Grouws (editor) Handbook of research on Mathematics Teaching. Editor : Douglas. NCTM. New York : Macmillan Publishing Company.

Karso. Dkk. 2006 . Pendidikan Matematika I. Jakarta : Universitas Terbuka.

Lange, J. de \& Verhage ,H. 2000. Mathematics Education and Assesment . Utrecht : Freudhental Institute. 
Marpaung, Y. 2006. Pembelajaran Matematika dengan Model PMRI. Yogyakarta : PPPG Matematika.

National Council of Teachers of Mathematics (NCTM). 2000. Principles and Stands for School Mathematics, USA : NCTM.

Ruseffendi, E.T. 1991. Penilaian Pendidikan dan Hasil Belajar Siswa Khususnya dalam Pengajaran Matematika untuk Guru dan Calon Guru. 